\title{
Kompleksitas Keamanan Kawasan dan Tantangan Kerja Sama Keamanan Asia Timur
}

\author{
M. Najeri Al Syahrin \\ Program Studi Hubungan Internasional \\ Universitas Muhammadiyah Kalimantan Timur - Indonesia \\ Email:mnas955@umkt.ac.id \\ Diserahkan: 8 Maret 2018 | Diterima: 17 Mei 2018
}

\begin{abstract}
This article will explain the regional security complex as a key challenge in the establishment of regional security cooperation in East Asia. The complex of security in East Asia described by explaining the security relations between North Korea and South Korea, China and Japan, the United States with Japan, and China with the United States and a pattern of chain reaction to the various security policies of these countries. This security complex makes it difficult to establish effective regional security cooperation. The Challenge of the regional security complex that most decisive in the formation of cooperation that will be done by the countries of the East Asia region is due to competition and differences of interests between the United States and China as a superpower state in the region. In addition, the many differences in the nature and orientation of political interests of Japan, South Korea, and North Korea are also still a constraint in the formation of regional security organizations and cooperation.
\end{abstract}

Keywords: Complexity; Security, Regional, Challenge.

\begin{abstract}
Abstrak
Artikel ini akan menjelaskan tentang kompleksitas keamanan kawasan sebagai tantangan utama dalam pembentukan kerja sama keamanan kawasan di Asia Timur. Kompleksitas keamanan yang terjadi di kawasan Asia Timur di uraikan dengan menjelaskan hubungan keamanan antara Korea Utara dan Korea Selatan, Cina dan Jepang, Amerika Serikat dengan Jepang, serta Cina dengan Amerika Serikat serta pola aksi-reaksi atas berbagai kebijakan keamanan negara-negara tersebut. Kompleksitas keamanan ini menyebabkan sulit terbentuknya kerja sama keamanan kawasan yang efektif. Tantangan dalam kompleksitas keamanan kawasan yang paling menentukan dalam pembentukan kerja sama yang akan dilakukan oleh negara-negara kawasan Asia Timur adalah karena kompetisi dan perbedaan kepentingan antara Amerika Serikat dan Cina sebagai negara adidaya di kawasan. Selain itu, banyaknya perbedaan sifat dan orientasi kepentingan politik Jepang, Korea Selatan dan Korea Utara juga masih menjadi kendala dalam pembentukan organisasi dan kerja sama keamanan kawasan.
\end{abstract}

Kata Kunci: Kompleksitas, Keamanan, Kawasan, Tantangan

\section{PENDAHULUAN}

Dalam upaya untuk memberikan respon terhadap setiap tantangan keamanan di kawasan, pengaturan kerja sama keamanan sangat mutlak diperlukan. Peningkatan eskalasi konflik cenderung mudah terjadi di kawasan akibat minimnya pengaturan kerja sama. Regionalisasi dan 
pembentukan institusi keamanan kawasan menjadi semakin krusial untuk dibutuhkan apabila koordinasi kebijakan antarnegara dilakukan secara intensif. Kerja sama kawasan juga berguna dalam proses penyelesaian konflik dan sengketa antarnegara di kawasan (Tang, 2009, 589-590).

Kawasan Asia Timur merupakan titik strategis di mana kepentingan negara-negara besar bertemu. Cina, Jepang, Korea Selatan dan Korea Utara saling berebut pengaruh politik dan ekonomi di kawasan ini. Kondisi ini semakin tidak menentu ketika Amerika Serikat juga ikut terlibat aktif dalam pengaturan keamanan di kawasan Asia Timur. Partisipasi aktif Amerika Serikat dalam aliansi militer trilateral dengan Jepang dan Korea Selatan menyebabkan stabilitas keamanan kawasan sangat dipengaruhi oleh interaksi keamanan negara-negara tersebut. Stabilitas keamanan yang tidak menentu akan menyebabkan kawasan dalam kondisi potensial untuk terjadinya konflik. Permasalahannya adalah selama ini, kawasan Asia Timur belum memiliki kerangka kerja sama dan institusi keamanan yang secara efektif mampu untuk meredakan tensi ketegangan antarnegara di kawasan.

Tulisan ini bertujuan untuk mendeskripsikan implikasi kompleksitas keamanan kawasan terhadap sulitnya pembentukan kerja sama keamanan kawasan yang efektif di Asia Timur. Urgensi tulisan ini terlihat dari uniknya kompleksitas kawasan dan hubungan keamanan di Asia Timur, khususnya antara Cina dengan Jepang, Korea Utara dan Korea Selatan, serta peranan Amerika Serikat di kawasan. Hal tersebut menjadi sangat menarik untuk diteliti karena kelima negara ini memegang peranan kunci dalam stabilitas kawasan, dilihat dari kapabilitas militer dan persenjataan nuklir yang dimiliki serta daya tawar politik dan ekonomi masing-masing negara.

Dua pertanyaan utama akan dijawab dalam tulisan ini. Pertama bagaimana gambaran tentang kompleksitas keamanan kawasan yang terjadi di kawasan Asia Timur. Pertanyaan kedua adalah bagaimana 
bentuk tantangan dan implikasi dari kompleksitas keamanan tersebut terhadap peluang pembentukan kerja sama keamanan kawasan, di tengah kondisi keamanan yang rumit antara negara-negara di kawasan Asia Timur. Kedua pertanyaan tersebut akan dijawab melalui deskripsi tentang peranan kekuatan eksternal yang mengambil bentuk masuknya negara luar ke dalam wilayah kawasan ataupun dibangunnya suatu kerja sama atau aliansi antara negara luar dengan satu atau beberapa negara dalam kawasan. Tanpa adanya kerja sama keamanan kawasan di Asia Timur, negara-negara cenderung akan menciptakan pola persahabatan yang mendasari terbentuknya formulasi kedekatan serta juga akan menciptakan pola permusuhan dalam suatu kawasan yang mungkin bisa berimplikasi pada terjadinya perang antarnegara.

\section{PEMBAHASAN}

\section{Kompleksitas Keamanan Kawasan Asia Timur}

Dalam menjelaskan tentang kompleksitas keamanan kawasan, perlu kiranya secara komprehensif terlebih dahulu memahami teori kompleksitas keamanan kawasan.

Kerangka analisis yang digunakan untuk menjawab pertanyaan dalam tulisan ini adalah kerangka teoritis yang dicetuskan oleh Barry Buzan (regional security complex theory) sebagai landasan dalam memahami rumitnya fenomena keamanan di kawasan Asia Timur. Dalam teori tersebut, Buzan berpendapat bahwa region bukanlah berarti berarti teritori saja, tetapi juga merupakan konsep kawasan yang mana proses sekuritisasi, desekuritisasi dan interaksi antara negara didalamnya saling terhubung dan memiliki keterkaitan. Masalah keamanan negara-negara dalam kawasan tersebut juga tidak dapat dianalisis secara terpisah (Buzan \& Waever, 2003, 54).

Secara sederhana, teori ini berfokus pada unsur-unsur pembentuk kompleksitas keamanan dalam suatu kawasan tertentu. Dalam uraian yang berbeda, Buzan dan Waever menyatakan bahwa faktor geografis, etnisitas, dan budaya masyarakat di suatu wilayah juga bisa 
menimbulkan kompleksitas keamanan kawasan, ketika terdapat ketergantungan dan hubungan keamanan antarnegara dalam kawasan tersebut. Secara khusus, hal ini kemudian akan juga mempengaruhi perkembangan sistem ekonomi dan politik yang akan menimbulkan saling ketergantungan antarnegara. Pada akhirnya, kondisi ini akan memunculkan sistem pertahanan keamanan kawasan dan aliansi militer akibat dari perubahan tersebut (Buzan \& Waever, 2003, 46-48).

Menurut Buzan dan Waever terdapat empat hal yang menjadi pembentuk struktur dasar dari terciptanya kompleksitas keamanan kawasan, yaitu kedekatan geografis, anarkisme kawasan, dan polaritas kekuatan serta konstruksi sosial berupa amity (pola persahabatan) dan enmity (pola permusuhan). Terbentuknya pola ketergantungan antarnegara tersebut baik ketergantungan yang bersifat amity maupun enmity dalam kompleks keamanan kawasan secara langsung akan menyebabkan persaingan antaranegara dan meningkatkan kecurigaan keamanan. Akibatnya aliansi keamanan dan masuknya kekuatan eksternal semakin intens terjadi dalam kondisi ini (Buzan \& Waever, 2003,. 53).

Teori ini menjelaskan tentang aspek-aspek pembentuk kompleksitas keamanan kawasan yang saling berhubungan dan memberikan aksireaksi dan timbal balik. Salah satu aspek penting dalam pembentuk kompleksitas keamanan kawasan adalah anarkisme kawasan. Anarkisme kawasan mengakibatkan minimnya dialog dan proses komunikasi dalam bentuk kerja sama atau perjanjian bilateral maupun multilateral sehingga mengakibatkan tingginya kecurigaan antarnegara. Anarkisme kawasan juga ditunjukkan dengan tidak adanya otoritas yang berwenang dalam proses penyelesaian secara damai apabila terjadi konflik di antara negara-negara kawasan Asia Timur (Buzan \& Waever, 2003, 53-54).

Keamanan suatu negara tidak bisa dipisahkan dengan keamanan negara lain, baik dari skala regional 
maupun global, karena kawasan merupakan arena di mana dinamika keamanan nasional dan keamanan global saling berkaitan dan mempengaruhi satu sama lain. Sebagai bukti di kawasan Asia Timur, dinamika keamanan global sangat mempengaruhi pola hubungan keamanan negara-negara dalam kawasan tersebut. Perseteruan ideologi antara Amerika Serikat dengan Uni Soviet pada masa Perang Dingin telah membuat kompetisi perseteruan antara dua negara Korea, Korea Utara dan Korea Selatan, dimana kini rivalitas keduanya membuat situasi keamanan Asia Timur semakin tidak menentu. Interaksi antara keamanan global dan regional memicu adanya intervensi negara adidaya yang pada akhirnya merubah persepsi ancaman dan pola keamanan antarnegara di kawasan (Buzan \& Waever, 2003, 131132).

Barry Buzan (1991) melengkapi penjelasan tentang teori kompleksitas keamanan kawasan dengan memberikan uraian bahwa proses sekuritisasi maupun desekuritasasi suatu negara merupakan proses interaksi terhadap keamanan negara lain. Dengan demikian, untuk memahami kompleksitas keamanan kawasan, tidak cukup hanya dengan memahami keamanan satu negara saja, tetapi juga harus memahami keamanan negara lain dan interaksi keamanan negara-negara tersebut. Terdapat juga beberapa aspek lain yang berpengaruh dalam pembentukan kompleksitas keamanan kawasan, yaitu kondisi keamanan domestik yang tidak stabil, interaksi antarkawasan dan juga peran kekuatan global. Dengan memahami aspek-aspek tersebut maka kompleksitas keamanan kawasan bisa dideskripsikan secara utuh dan komprehensif (Buzan, 1991, 53-54).

Kompleksitas keamanan kawasan Asia Timur dapat dipahami dengan mengurai kerumitan antara hubungan keamanan Cina, Korea Utara, Korea Selatan, Jepang dan Amerika Serikat. Kerumitan hubungan tersebut dapat terlihat pada persepsi Cina dan Korea Selatan yang mencurigai upaya Jepang yang ingin melakukan revisi sejarah pendudukannya di Semenanjung 
Korea dan sebagian wilayah Cina pada awal abad ke-20. Hubungan Cina dan Korea Selatan juga tidak sepenuhnya mulus. Cina telah menyampaikan keberatannya atas rencana penempatan sistem antirudal canggih Korea Selatan yang dipasang untuk mewaspadai ancaman nuklir Korea Utara. Hal tersebut dinilai Cina mencerminkan keinginan Amerika Serikat untuk mengawasi Cina. Sengketa wilayah juga semakin memperumit hubungan keamanan antara negara-negara tersebut, Cina dan Jepang masih bersengketa soal pulau Diaoyu atau Senkaku di Laut Cina Selatan. Cina dan Korea Selatan juga masih terlibat dalam sengketa wilayah dengan Jepang soal sejumlah pulau di Laut Cina Timur dan perairan antara Jepang dan Korea Selatan (Kwaak, 2015).

Pertumbuhan ekonomi Cina dianggap menjadi ancaman baru tidak hanya bagi Amerika Serikat tetapi juga bagi Korea Selatan dan Jepang. Permasalahan ini dikarenakan kekuatan ekonomi akan menunjang perkembangan militer dan modernisasi sistem persenjataan Cina. Didukung dengan pertumbuhan ekonomi, maka pertumbuhan militer akan tumbuh beriringan. Peningkatan kapabilitas militer tersebut merupakan bentuk modernisasi yang dilakukan dengan meningkatkan anggaran belanja dengan fokus pembaruan alutsista dan sistem persenjataan. Perkembangan kekuatan militer Cina pasti akan membuat khawatir Amerika Serikat dan negara aliansinya di Asia Timur seperti Jepang dan Korea Selatan. Upaya untuk membendung kekuatan Cina tersebut di lakukan dengan semakin meningkatkan hubungan keamanan dan mitra strategis tidak hanya dengan Jepang tetapi juga dengan Korea Selatan. Kunjungan Trump pada November 2017 ke Jepang dan Korea Selatan merupakan salah satu bukti bahwa Amerika Serikat selalu menjadikan kepentingan keamanan Asia Timur menjadi salah satu prioritas utama kebijakan luar negerinya. Oleh karena itu dalam beberapa tahun ini, Amerika Serikat selalu menempatkan kepentingan yang strategis di kawasan dengan tujuan 
utama untuk membendung pengaruh dan hegemoni Cina (Goo \& Lee, 2014, p. 337).

Uniknya dalam hubungan keamanan Asia Timur, bagi Korea Selatan, Cina tidak selalu menjadi ancaman yang mengkhawatirkan bagi keamanan nasionalnya. Ancaman yang nyata bagi Korea Selatan bukanlah Cina, tetapi Korea Utara. Oleh karena itu, upaya untuk membendung kekuatan Korea Utara selalu diupayakan Korea Selatan dalam aliansi strategisnya dengan Amerika Serikat. Dalam aliansinya tersebut, Korea Selatan tidak selalu merespon aktif segala kebijakan yang berkaitan dengan Cina, karena fokus utama ancaman keamanan Korea Selatan adalah Korea Utara. Disisi yang lain, secara historis bahkan Korea Selatan dan Cina sama-sama memiliki sifat sentimen yang tinggi terhadap Jepang. Sementara bagi Jepang, Cina merupakan permasalahan utama keamanan di kawasan, Jepang selalu memberikan respon aktif terkait dengan permasalahan Cina. Dengan menguatnya peranan Cina yang memiliki potensi untuk mendominasi Asia Timur, Jepang selalu merasa kredibilitasnya di kawasan akan terancam. Ancaman tersebut akan berdampak langsung bagi Jepang, karena secara geografis berada dekat dengan Cina, sehingga ia merasa perlu melakukan penguatan kembali dengan upaya menekan perkembangan militer Cina. Bagi Jepang, peningkatan kekuatan militer dan sistem persenjataan Cina memberikan ancaman yang serius terhadap keamanan nasionalnya dan kepentingan Jepang tidak hanya di kawasan tetapi juga pada ranah global (Goo \& Lee, 2014, 337).

Bagi Jepang, Cina dan Korea Utara merupakan ancaman serius bagi stabilitas keamanan kawasan Asia Timur, sementara bagi Cina dan Korea Utara, Amerika Serikat, Jepang, dan Korea Selatan yang tergabung dalam aliansi keamanan justru mengancam negara-negara lain di kawasan. Meskipun demikian, hubungan antara Jepang dan Korea Selatan juga tidak selalu harmonis, meskipun keduanya sama-sama merupakan mitra 
keamanan Amerika Serikat (Goo \& Lee, 2014, 337). Kerumitan hubungan antarnegara tersebut semakin meningkatkan kecurigaan dan menambah kompleksitas keamanan kawasan.

\section{Permasalahan Semenanjung} Korea juga merupakan salah satu aspek penting dalam kompleksitas keamanan kawasan Asia Timur. Pengembangan senjata nuklir yang dilakukan oleh Korea Utara merupakan salah satu cara dan upaya manuver politik untuk meningkatkan posisi tawar di dunia internasional, khususnya terhadap Amerika Serikat dan negara-negara aliansinya di kawasan Asia Timur (Mochammad, 2010, 27-29). Upaya Amerika Serikat untuk melakukan normalisasi hubungan dengan Korea Utara sudah dilakukan sejak masa akhir Perang Dingin. Upaya rekonsiliasi konflik guna meredam ketegangan kawasan akibat perkembangan nuklir Korea Utara adalah dengan menyepakati kerangka kerja sama keamanan senjata nuklir. Six Party Talks merupakan kerangka kerja sama yang di sepakati pada tahun 2003, dengan melibatkan Korea Utara, Korea Selatan, Cina, Jepang, Amerika Serikat dan Rusia. Kerja sama ini merupakan bukti dan perwujudan upaya alternatif yang ditawarkan Amerika Serikat untuk meredam ketegangan konflik militer dan perlombaan senjata di kawasan Asia Timur (Armstrong, 2006, 11). Meskipun hingga kini, Amerika Serikat masih kesulitan untuk mengajak Korea Utara untuk menghentikan provokasi nuklimya. Alhasil ketegangan di kawasan akibat pengembangan nuklir Korea Utara tersebut masih terus terjadi.

Argumen menarik lainnya yang disampaikan oleh Armstrong (Armstrong dikutip Feffer, 2006, 11 13) menyatakan bahwa gagalnya upaya perundingan antara Amerika Serikat dengan Korea Utara dalam masalah nuklir adalah karena Amerika Serikat dianggap tidak berhasil dalam mendorong upaya harmonisasi hubungan antara Korea Utara dan Korea Selatan. Sehingga hal tersebut menciptakan terjadinya dilema keamanan antara kedua negara 
tersebut. Selama ini, perjanjian dan kesepakatan dalam kerja sama yang sudah dilakukan masih tidak efektif dan belum mampu menghilangkan dilema keamanan yang terjadi. Korea Utara masih menyakini bahwa Amerika Serikat sebagai negara musuh dan anti rezim Korea Utara. Kecaman yang sering dilontarkan oleh Presiden Amerika Serikat, Donald Trump semakin memperkeruh suasana dan hubungan antara kedua negara. Persepsi itulah yang kini semakin menyulitkan Amerika Serikat dalam melakukan harmonisasi hubungan di Semenanjung Korea. Padahal harmonisasi tersebut merupakan salah satu faktor penting dalam upaya rekonsiliasi konflik di kawasan.

Kebijakan Korea Utara terus dipantau oleh Korea Selatan, Jepang dan Amerika Serikat. Dalam hal ini penting juga untuk melihat reaksi Cina dalam kebijakan keamanan Korea Utara. Kebijakan Korea Utara yang ingin melakukan serangan ke pulau Yeonpyeong dan negara Guam, merupakan salah satu upaya untuk melihat apakah Cina akan menentang kebijakan Korea Utara tersebut. Paska rencana tersebut, meskipun kini tidak terealisasi, Cina terbukti bersikap pasif dan terkesan membiarkan kebijakan provokatif Korea Utara tersebut. Hal ini tentu saja secara tidak langsung menyatakan bahwa Cina bersikap tidak kooperatif dalam upaya normalisasi hubungan antar dua Korea (Saunders 2012, 17).

Untuk memahami kondisi tersebut, dari sudut pandang Cina, ia menilai bahwa kebijakan provokatif Korea Utara merupakan respon atas kebijakan pembentukan aliansi militer Amerika Serikat, bagi Korea Utara jelas untuk selalu menunjukan bahwa Korea Utara bukanlah negara lemah. Cina juga menyadari bahwa negaranya hanya memiliki sedikit pengaruh bagi rezim Korea Utara. Kemampuan senjata nuklir telah menjadikan Korea Utara kini sudah tidak terlalu bergantung kepada Cina, seperti pada masa Perang Korea dahulu. Jadi sangat penting bagi Cina untuk secara cermat mempetakan posisi Korea Utara sebagai negara mitra dalam kerja sama kawasan. 
Di sisi yang lain, Korea Utara dinilai masih sulit untuk diajak bekerja sama dalam hubungan antarnegara di kawasan. Dari sudut pandang Amerika Serikat, terkait pasifnya Cina dalam masalah Korea Utara merupakan refleksi ketakutan atas runtuhnya rezim Korea Utara yang secara tidak langsung akan berdampak pada kuatnya posisi strategis Amerika Serikat di kawasan Asia Timur. Bagi Cina, sangat jelas untuk mencegah runtuhnya Korea Utara yang akan mengarah kepada reunifikasi Korea. Sehingga secara tidak langsung akan melemahkan posisi Cina untuk melawan hegemoni Amerika Serikat di kawasan Asia Timur. Selain itu, dengan kondisi konflik di Semenanjung Korea, perhatian Amerika Serikat akan terus tertuju kepada permasalahan Korea Utara, sehingga akan memudahkan Cina dalam melakukan kebijakan keamanan dan peningkatan senjata militer tanpa terlalu menarik perhatian Amerika Serikat (Saunders, 2012, 17-18).

Menurut Saunders (2012, 27), untuk memahami bagaimana hubungan antara Cina dan Korea Utara penting juga sebelumnya untuk mengetahui kebijakan Amerika Serikat terhadap Jepang dan Korea Selatan. Kebijakan Amerika Serikat terhadap kedua negara tersebut akan memberikan reaksi terhadap hubungan Korea Utara dengan Cina. Kerja sama trilateral Amerika Serikat di kawasan merupakan salah satu faktor untuk memahami bagaimana reaksi Cina terhadap Korea Utara. Dari sudut pandang negara-negara aliansi Amerika Serikat, persepsi ancaman keamanan tersebut cenderung berbeda, bagi Korea Selatan ancaman nuklir Korea Utara merupakan permasalahan paling serius di kawasan dan harus segera diselesaikan. Sementara bagi Jepang, peningkatan anggaran militer Cina merupakan permasalahan utama yang memicu ketegangan di kawasan.

Perbedaan cara pandang dan persepsi ancaman inilah yang membuat keamanan kawasan Asia Timur menjadi semakin kompleks dan menyulitkan negara-negara tersebut untuk saling bekerja sama. 
Pertumbuhan ekonomi dan militer Cina yang dikhawatirkan akan menjadi pesaing strategis Amerika Serikat dalam upaya melakukan dominasi global telah membuat Amerika Serikat selalu mewaspadai kebijakan politik dan keamanan yang dilakukan oleh Cina, meskipun Cina tidak secara langsung mengeluarkan kebijakan keamanan yang bersifat agresif. Kekhawatiran Amerika Serikat terhadap Cina selalu dibandingkan dengan Uni Soviet pada masa Perang Dingin. Uni Soviet pada masa Perang Dingin memang bertujuan untuk mengimbangi kekuatan Amerika Serikat. Konfrontasi kebijakan yang dilakukan Uni Soviet berupaya untuk terus membendung hegemoni global Amerika Serikat. Untuk kasus Cina, dinilai sedikit berbeda, Cina tidak selalu bersifat provokatif dan lebih pasif dalam upaya konfrontasi ekonomi dengan Amerika Serikat. Bahkan, kini Cina sangat aktif dalam berpartisipasi secara bersama-sama dalam peningkatan ekonomi global melalui organisasi dan rezim internasional (Saunders, 2012, 7).
Peningkatan anggaran belanja militer yang sudah dilakukan Cina dianggap wajar dan masih bersifat defensif. Cina dalam buku putih pertahanan (defense white paper), menyatakan bahwa kebijakan pertahanannya bersifat active defensive (Information Office of the State Council, 2013, 13-16).

Hubungan keamanan negaranegara di kawasan Asia Timur tersebut memberikan risiko tersendiri bagi kawasan, apalagi ditambah dengan kehadiran Amerika Serikat dalam interaksi keamanannya. Potensi kompetisi antarnegara ini mulai terlihat ketika Amerika Serikat, Jepang, dan Cina saling berebut pengaruh di kawasan dan memungkinkan terjadinya benturan kepentingan yang dapat memicu terjadinya konflik dan ketidakstabilan keamanan kawasan Asia Timur yang pada akhirnya saling menyulitkan negara-negara untuk saling bekerja sama. Cina memegang peranan penting seiring dengan peningkatan kapabilitas nasionalnya. Peningkatan kapabilitas nasional Cina tersebut dilihat sebagai tantangan bagi kepentingan nasional tidak hanya bagi 
Amerika Serikat, tetapi sekaligus juga bagi negara aliansi Amerika Serikat di Kawasan Asia Timur. Permasalahan Semenanjung Korea juga merupakan salah satu aspek yang paling memberikan pengaruh dalam kompleksitas keamanan kawasan Asia Timur (Veronica, 2011, 162). Hal ini kemudian diperparah dengan adanya konflik masa lalu antara negara-negara di kawasan Asia Timur. Perang Korea dan invasi Jepang terhadap Cina merupakan contoh bahwa faktor historis juga memberikan implikasi dalam tingginya kecurigaan dan kewaspadaan keamanan di kawasan. Pada akhirya kondisi ini memunculkan skeptimisme akan adanya kerja sama yang efektif di kawasan guna mendukung terciptanya stabilitas keamanan kawasan.

\section{Kompleksitas Keamanan Kawasan Sebagai Tantangan Kerja Sama Di Asia Timur}

Dua atau lebih unit-unit otonom menciptakan kondisi anarkis di kawasan Asia Timur. Artinya, apabila kebijakan keamanan suatu negara bersifat provokatif, maka akan memicu respon dari negara lain, begitu pula sebaliknya. Hal ini menandakan bahwa suasana persaingan dan kecurigaan masih sangat tinggi terjadi, sehingga akhirnya akan menjadi pemicu permusuhan antarnegara. Kondisi ini kemudian juga akan menciptakan anarkisme kawasan yang pada akhirnya mengakibatkan minimnya dialog dan proses komunikasi antarnegara dalam bentuk kerja sama regional maupun multilateral.

Kondisi ini semakin tidak menentu apabila terjadi konflik antarnegara di kawasan, tidak adanya otoritas yang berwenang dalam proses penyelesaian konflik secara damai akan memungkinkan negara-negara untuk berperang guna menyelesaikan permasalahan mereka. Pembentukan kerja sama atau rezim keamanan yang efektif dinilai sangat perlu untuk dilakukan dalam upaya mengatasi permasalahan keamanan tersebut. Dalam upaya menciptakan rezim atau institusi keamanan kawasan, terdapat dua hal utama yang perlu dilakukan. 
Pertama, faktor-faktor diluar kawasan khususnya peranan Amerika Serikat yang ikut mempengaruhi pembentukan kerja sama kawasan mutlak sangat diperhatikan oleh negara-negara di kawasan Asia Timur. Tekanan internasional dan tata kelola global terkait dengan permasalahan ekonomi dan keamanan Amerika Serikat dinilai akan mempengaruhi terbentuknya kerja sama antarnegara di kawasan Asia Timur. Kebijakan keamanan Amerika Serikat selalu berupaya untuk menciptakan organisasi keamanan multilateral atau regional untuk mengatur permasalahan keamanan. Pembentukan NATO (North Atlantic Treaty Organization) dan SEATO (South East Asia Treaty Organization) merupakan bukti bahwa kebijakan untuk menciptakan organisasi keamanan selalu diupayakan oleh Amerika Serikat (Austin \& Harris, 2001, 280).

Kawasan Asia Timur juga merupakan salah satu kawasan yang secara resmi diumumkan Amerika Serikat sebagai kawasan strategis di dunia. Strategi rebalancing yang difokuskan ke kawasan Asia-Pasifik dan Asia Timur secara khusus, telah mengubah paradigma keamanan Amerika Serikat kontemporer. Penarikan pasukan dari kawasan Timur Tengah memperkuat indikasi adanya perubahan strategi dalam kebijakan militer Amerika Serikat ke kawasan Asia Pasifik dan Asia Timur. Penarikan pasukan, sebanyak 60\% yang dulunya berada di Timur Tengah yang kemudian ditempatkan di bawah komando The United States Pacific Command (USPACOM) merupakan bukti bahwa Amerika Serikat menganggap kawasan Asia Timur merupakan salah satu kawasan strategis global (Planifolia, 2017, 1).

Kedua, keterlibatan aktif Cina selalu memiliki peran penting dalam pembentukan kerja sama di kawasan. Bentuk kerja sama akan banyak dipengaruhi oleh kepentingan yang terhubung dengan kepentingan Cina. Keterlibatan Cina akan membuka peluang bagi terbentuknya kerja sama kawasan, karena Cina memiliki letak geografis yang strategis serta didukung oleh kekuatan ekonomi dan militernya. 
Apabila Cina melihat banyak kepentingan yang akan diraih apabila institusi keamanan kawasan Asia Timur terbentuk, maka akan ada upaya aktif Cina untuk ikut berpartisipasi dalam rezim keamanan regional. Menurut Shambaugh (2005) dalam beberapa tahun terakhir, interaksi antarnegara di kawasan Asia Timur sangat dipengaruhi oleh meningkatnya kekuatan ekonomi, militer serta keterlibatan aktif Cina dalam organisasi internasional dan kerja sama multilateral. Sehingga sangat wajar dalam beberapa tahun ke depan hubungan antarnegara di kawasan akan dipengaruhi oleh respon dan persepsi terhadap politik luar negeri Cina sebagai kekuatan baru global.

Selain terus berupaya mengembangkan kekuatan ekonomi, Cina juga terus berupaya untuk mengembangkan pengaruh politiknya di antara negara-negara kawasan Asia Timur. Bagi Cina pembentukan organisasi kawasan, baik di kawasan Asia Timur maupun kawasan lain di Asia, selalu didominasi oleh kepentingan Amerika Serikat. Ini meliputi juga kerja sama keamanan antara Amerika Serikat dengan Jepang dan Korea Selatan. Meskipun pengembangan ekonomi dan politik selalu dilakukan oleh Cina di kawasan, pembentukan organisasi keamanan kawasan bagi Cina hanya akan selalu didominasi oleh kepentingan dan hegemoni Amerika Serikat. Upaya dominasi tersebut merupakan bentuk konfirmasi atas adanya kekhawatiran Amerika Serikat terhadap peningkatan kapabilitas yang sudah dilakukan oleh Cina. Posisi dominan Amerika Serikat di kawasan Asia Timur tersebut selalu diupayakan dengan pembentukan mitra keamanan dengan Jepang dan Korea Selatan. Hal tersebut diharapkan bisa memberikan jaminan kepentingan Amerika Serikat. Meskipun pada awalnya pembentukan aliansi tersebut berfungsi untuk membendung pengaruh komunisme di kawasan Asia Pasifik, tetapi kini aliansi tersebut bisa berkembang ke berbagai aspek kerja sama strategis lainnya (Austin \& Harris 2001, 21). Aliansi tersebut dilihat oleh Cina hanya sebagai upaya perluasan dominasi 
ekonomi dan politik Amerika Serikat.

Melihat kondisi tersebut sangat sulit bagi Cina untuk menjadikan pembentukan organisasi kawasan menjadi prioritas kebijakan keamanan Cina di kawasan. Perbedaan pandangan inilah yang kemudian menjadi kendala bagi pembentukan kerja sama kawasan, padahal peran Amerika Serikat dan Cina sangat penting dalam pembentukan organisasi keamanan kawasan.

Selain itu, untuk memahami bagaimana kerja sama keamanan yang efektif dalam meminimalisir konflik di kawasan, terdapat aspek penting dalam proses implementasi kerja sama kawasan, yaitu terbentuknya institusi kawasan. Kerja sama keamanan yang efektif berupa terbentuknya institusi kawasan diharapkan bisa mengurangi kerumitan hubungan keamanan antarnegara selain tentunya sebagai sarana efektif untuk meminimalisir dan menyelesaikan konflik. Terdapat beberapa perubahan paradigma dalam pembentukan institusi kerja sama keamanan di kawasan Asia Timur pasca Perang Dingin. Permasalahan internal negara-negara di kawasan, dianggap menjadi permasalahan pokok yang menjadi alasan sulitnya negaranegara tersebut untuk saling bekerja sama. Permasalahan nuklir di Semenanjung Korea, kompetisi antarnegara adidaya khususnya antara Cina dan Amerika Serikat, dan kerja sama pertahanan trilateral antara Amerika Serikat, Korea Selatan dan Jepang menjadi hambatan utama dalam pembentukan institusi keamanan di kawasan Asia Timur (Work, 2015).

Beberapa perubahan positif tetap terjadi di Asia Timur, ditengah banyaknya problematika dan kendala dalam pembentukan institusi kerja sama di kawasan. Perubahan tersebut berwujud aktivitas kerja sama antarnegara Asia Timur yang dilakukan dengan kawasan lain seperti ASEAN atau Uni Eropa. Diharapkan, perkembangan ini dinilai tidak hanya akan meningkatkan kerja sama antara negara-negara antarkawasan saja, tetapi juga perkembangan terbentuknya institusi di kawasan Asia 
Timur sendiri (Austin \& Harris, 2001, 277).

Proses regionalisasi akan dianggap efektif apabila bisa memenuhi beberapa instrumen berikut, yaitu jaminan terhadap perdamaian, adanya transparansi proses pengambilan keputusan, peningkatan ekonomi dan distribusi manfaat dan keuntungan yang didapat dari proses integrasi tersebut secara adil kepada seluruh negara yang berpartisipasi di kawasan. Terdapat beberapa contoh keberhasilan regionalisasi ekonomi kawasan, seperti Uni Eropa atau North American Free Trade Agreement (NAFTA). Pada awalnya organisasi- organisasi tersebut tercipta karena adanya kebutuhan ekonomi, seiring berjalan waktu cakupan kerja sama didalamnya berkembang lebih luas termasuk juga kerja sama dalam aspek keamanan. Hal ini mengindikasikan bahwa ekonomi bisa menjadi faktor penentu dan memiliki dampak pada peningkatan hubungan politik dan keamanan antarnegara dalam proses regionalisasi kawasan (Tsuneo dikutip Mori \& Kenichiro, 2007, 187).

Dengan menjadikan ekonomi sebagai pemicu dalam pembentukan keamanan kawasan masih sulit untuk diterapkan di Asia Timur, karena struktur politik dan ekonomi antarnegara di kawasan sangat berbeda. Hal inilah yang yang masih juga menjadi kendala lain dalam pembentukan kerja sama keamanan yang efektif di kawasan. Kehadiran dan intervensi Amerika Serikat juga dianggap berbeda dengan yang sudah terjadi di Amerika Utara (NAFTA). Di kawasan Amerika Utara, Amerika Serikat secara langsung berupaya secara aktif untuk melakukan stabilitasi dan integrasi ekonomi melalui organisasi NAFTA. Sedangkan di kawasan Asia Timur, Amerika Serikat dan Cina tidak menjadikan integrasi ekonomi kawasan menjadi prioritas utama. Kebijakan Amerika Serikat lebih banyak berfokus pada rivalitas politik dan ideologi antarnegara kawasan yang terkait dengan konfrontasi dengan Uni Soviet pada masa Perang Dingin. Kini, kebijakan 
Amerika Serikat lebih banyak berorientasi pada kebijakan keamanan dan militer dan upaya untuk membendung pengaruh Cina. Orientasi kebijakan Amerika Serikat di kawasan masih berfokus rivalitas antarnegara sehingga sulit untuk saling mencapai kesepakatan dalam kerja sama (Tsuneo dikutip Mori \& Kenichiro, 2007, 187).

Kondisi tersebut pada akhirnya mengakibatkan munculnya dua hierarki utama di kawasan Asia Timur. Hierarki keamanan didominasi oleh Amerika Serikat, dan hierarki ekonomi yang didominasi oleh Cina. Negaranegara di kawasan tersebut, khususnya Jepang dan Korea Selatan selalu mengandalkan Amerika Serikat untuk memberikan jaminan keamanan. Sistem aliansi yang dipimpin Amerika Serikat telah berjalan dengan baik selama berpuluh-puluh tahun. Pada saat yang sama, sebagian besar negara di kawasan Asia Timur semakin terikat juga dengan Cina dalam hal perdagangan dan investasi. Selama beberapa dekade terakhir, negaranegara yang sebelumnya menjadikan
Amerika Serikat sebagai negara mitra dagang seperti Jepang dan Korea Selatan, sekarang mulai beralih untuk menjadikan Cina sebagai mitra dagang yang utama. Dewasa ini, meskipun Amerika Serikat masih dianggap sebagai negara dengan kekuatan ekonomi dan militer yang berpengaruh di dunia. Tetapi, kini Cina dinilai sudah bisa mengimbangi kekuatan militer dan pengaruh politik Amerika Serikat tersebut, setidaknya di kawasan Asia Timur. Tingginya pertumbuhan ekonomi Cina membuat negaranya mampu melakukan akselerasi dalam modernisasi militer. Meskipun Amerika Serikat masih merupakan negara dengan kemampuan ekonomi dan pasar yang potensial di dunia, namun Cina adalah pusat ekonomi baru di wilayah Asia dan diprediksi akan terus berkembang sebagai negara adidaya ekonomi di masa depan (Ikenberry， 2016，9-11). Banyak kalangan menilai bahwa kebangkitan Cina tersebut, baik secara ekonomi maupun militer, akan berimplikasi langsung terhadap kepentingan Amerika Serikat di kawasan Asia 
Timur dan secara langsung akan menjadikan Cina sebagai ancaman potensial bagi kepentingan Amerika Serikat di kawasan Asia Timur (Katzenstein, 2012, 21-22).

Membuktikan

keseriusan

Amerika Serikat untuk semakin menguatkan pengaruhnya di kawasan Asia Timur, Presiden Amerika Serikat, Donald Trump telah melakukan kunjungan kenegaraan ke Jepang dan Korea Selatan serta beberapa negara Asia lainnya untuk mewaspadai peningkatan pengaruh dan dominasi Cina di kawasan. Perjalanan Trump yang dilakukan selama 12 hari pada November 2017, dilontarkan oleh Washington sebagai cara untuk meredakan kekhawatiran terhadap Cina serta menunjukkan komitmen yang tinggi terhadap kondisi keamanan kawasan Asia Timur (Holmes, 2017). Namun sisi menariknya dari hubungan rivalitas ini adalah beberapa negara seperti Jepang dan Korea Selatan, cenderung untuk menginginkan hierarki ganda ini terjadi di kawasan. Mereka tidak ingin membuat pilihan secara langsung untuk memilih berada di kubu Amerika Serikat ataupun Cina. Mereka ingin menerima manfaat keamanan dari bersekutu dengan Amerika Serikat dan juga mendapat keuntungan ekonomi dari perdagangan dengan Cina (Ikenberry, 2016, 9-11).

Atas kondisi ini, akibatnya Amerika Serikat dan Cina akan semakin bersaing untuk mempengaruhi negara- negara lain di kawasan. Dalam kompetisi hegemonik ini, Amerika Serikat dan Cina samasama menawarkan keuntungan dari kepemimpinan mereka di kawasan tanpa berupaya untuk saling bekerja sama. Mereka masing-masing memiliki 'stick and carrot' untuk mendorong negara-negara di kawasan Asia Timur sebagai negara mitra utama. Amerika Serikat menawarkan sistem kerja sama dan aliansi yang bisa menjadi aset keamanan, dan Cina menawarkan aset perdagangan dan investasinya. Rivalitas ini tentu akan sulit dalam mencapai konsensus bersama dalam pembentukan kerja sama keamanan kawasan, karena Amerika Serikat dan Cina cenderung memiliki kepentingan 
ekonomi dan politik yang berbeda (Ikenberry, 2016, 9-11).

Kompleksitas keamanan kawasan di Asia Timur pada dasarnya menjelaskan tentang kondisi keamanan Cina, Jepang, Korea Selatan, dan Korea Utara yang tidak stabil karena terjadi persaingan antara negara-negara besar. Kompleksitas keamanan kawasan tersebut juga semakin rumit dengan meningkatnya peran Cina di kawasan baik dalam aspek militer, ekonomi maupun politik. Perkembangan kekuatan militer dan ekonomi Cina semakin meningkatkan kecurigaan dan rivalitas antarnegara di kawasan Asia Timur. Rivalitas tersebut pada akhirnya menjadi hambatan dan kendala bagi pembentukan organisasi dan kerja sama kawasan.

\section{KESIMPULAN}

Kerja sama keamanan di kawasan Asia Timur masih sulit terjalin karena banyaknya hambatan dan kendala bagi setiap negara di kawasan. Hambatanhambatan tersebut antara lain berupa kompetisi antarnegara adidaya. Pada masa Perang Dingin, terdapat konfrontasi ideologi antara Amerika Serikat dengan Uni Soviet yang membuat Amerika Serikat bergabung dengan aliansi Jepang dan Korea Selatan dan Uni Soviet bersama dengan Cina dan Korea Utara. Kini persaingan strategis juga terjadi antara Amerika Serikat dengan Cina. Hierarki keamanan yang didominasi oleh Amerika Serikat, dan yang lainnya adalah hierarki ekonomi yang didominasi oleh Cina. Persaingan tersebut tidak hanya terjadi di antara negara-negara kawasan saja, tetapi juga negara di luar kawasan.

Perbedaan kepentingan antara Cina dan Amerika Serikat juga menjadi permasalahan krusial, bagi Cina pembentukan organisasi keamanan kawasan hanya akan selalu didominasi oleh kepentingan Amerika Serikat. Begitupula sebaliknya, bagi Amerika Serikat, regionalisasi dan pembentukan institusi kawasan akan menjadikan pengaruh dan dominasi Amerika Serikat terhadap negara-negara Asia Timur akan berkurang, dan hal ini akan menyebabkan Cina bisa semakin 
meluaskan pengaruhnya di kawasan. Upaya dominasi tersebut merupakan bentuk konfirmasi atas adanya rasa kekhawatiran Amerika Serikat terhadap peningkatan kapabilitas hegemoni yang akan dilakukan oleh Cina, begitupula sebaliknya.

Banyaknya perbedaan sifat dan orientasi kepentingan politik antarnegara kawasan Asia Timur juga masih menjadi kendala-kendala dalam pembentukan organisasi dan kerja sama kawasan. Sampai saat ini, berbagai perjanjian, perundingan, dan kesepakatan yang sudah terjalin belum efektif dalam upaya menyelesaikan ketegangan dan kompleksitas keamanan yang terjadi di kawasan Asia Timur.

Kompleksitas keamanan ini pada akhirnya akan berbahaya bagi stabilitas keamanan tidak hanya kawasan Asia Timur saja, tetapi juga kawasan lain di sekitarnya. Selain itu, anarkisme kawasan akibat tidak adanya aturan dan kesepakatan bersama dalam keamanan akan menguras biaya dan perhatian yang sangat besar dari negara kawasan maupun negara lain yang berkepentingan di kawasan Asia Timur. Pada akhirnya, anarkisme kawasan ini akan mengakibatkan hubungan keamanan antarnegara kawasan menjadi tidak seimbang serta selalu dipenuhi kecurigaan dan ketegangan satu sama lainnya. Ketidakseimbangan hubungan antarnegara di kawasan akan memunculkan kondisi tertentu, yaitu ketika suatu negara tidak bisa mengikuti dinamika keseimbangan tersebut dan akhirnya rentan menjadi sasaran dominasi negara lain.

\section{REFERENSI}

Armstrong, C.K. (2006) US-North Korean Relations dalam J. Feffer (ed.), the Future of US-Korean Relations, London: Routledge, pp. 10-26.

Austin, G. \& Harris, S. (2001) Japan and Greater China: Political Economy and Military Power in the Asian Century, Honolulu: University of Hawai Press.

Buzan, B. (1991) People, States and Fear: An Agenda for International Security Studies in the Post Cold War Era, Hempstead: Harvester Wheatsheaf.

Buzan, B. \& Waever, O. (2003) Regions and Powers: The Structure of International Security, New York: Cambridge University Press.

Goo, Y.W. \& Lee, S.H. (2014) "Military Alliances and Reality of Regional Integration: Japan, South Korea, the 
US vs. China, North Korea", Journal of Economics Integration, Vol. 29, No. 2, pp. 332-347.

Holmes, O. (2017) Trump skips East Asia Summit on Final Day of 12-Day Tour (Online). Tersedia di: https://www.theguardian.com/usnews/2017/nov/14/donald-trumpskips-east-asia-summit-on-final-dayof-12-day-tour. (Diakses: 28 Februari 2018).

Ikenberry, G.J. (2016) 'Between the Eagle and the Dragon: America, China, and Middle State Strategies in East Asia', The Journal of Public and International Affairs, Vol. 131, No 1.

Information Office of the States Council. (2013) The Diversified Employment of China's Armed Forces (Online). Tersedia di:

http://www.bjreview.com.cn/docum ent/txt/2013-

04/17/content_533917.htm (Diakses:

13 Januari 2018).

Katzenstein, J. (2012) China’s Rise: Rupture, Return, or Recombination,' dalam J. Katzenstein (ed.), Sinicization and the Rise of China: Civilizational Processes Beyond East and West, New York: Routledge, pp. 21-22.

Kwaak, J.Y. (2015) Menlu Negara Asia Timur Ingin Kurangi Ketegangan (Online). Tersedia di: http://indo.wsj.com/posts/2015/03/ 23/menlu-negara-asia-timur-inginkurangi- ketegangan/ (Diakses: 28 Desember 2017).

Lake, D.A. \& Morgan, M. (1997) Regional Organs: Building Security in a New World, Pennsylvannia: Pennsylvannia State University Press.
Mochammad, Y. (2010) "Perspektif Game Theory dalam konflik Amerika Serikat- Korea Utara", Verity, Vol. 2, No. 3, pp. 27-29.

Planifolia, V. (2017) "Strategi Rebalancing Amerika Serikat di Kawasan AsiaPasifik", Jurnal Hubungan Internasional, Vol. 6, No. 1, pp. 1-12.

Saunders, J. (2012) Extended Deterrence and Security in East Asia: A U.S.-JapanSouth Korea Dialogue, Washington, D.C: Centre for National Interest.

Shambaugh, D. (2005) The Rise of China and Asia's New Dynamics dalam D. Shambaugh (ed.), Power Shift: China and Asia's New Dynamics, California: University of California Press.

Tang, S. (2009) "Security Dilemma: A Conceptual Analysis", Security Studies, Vol. 18, No. 3, pp. 589-590.

Tsuneo. (2007) Non Traditional Security Cooperatioon for Regionalism in Northest Korea, dalam K. Mori \& W. Kenichiro (eds.), A New East Asia: Toward a Regional Community, Singapore: National University of Singapore Press.

Veronika, N.W. (2011) “Dari Uang ke Senjata: Kompetisi Ekonomi dan Pengaruhnya terhadap Keamanan Kawasan Asia Pasifik", Jurnal Ilmiah Hubungan Internasional, Vol. 7, No.2, pp. 159-163.

Work, C. (2015) Korea and the New Regional Paradigm: South Korea is at Center Stage of an Emerging New Paradigm in Northeast Asia (Online). Tersedia di: https://thediplomat.com/2015/04/k orea-and-the-new-regional-paradigm/ (Diakses: 24 Desember 2017). 